\begin{tabular}{|c|c|}
\hline ANGLES & Angles \\
\hline $\begin{array}{l}\text { NEW PERSPEETUEES } \\
\text { ANGLOPHONE WDRLD }\end{array}$ & New Perspectives on the Anglophone World \\
\hline & $\begin{array}{l}7 \mid 2018 \\
\text { Digital Subjectivities }\end{array}$ \\
\hline
\end{tabular}

\title{
Graphic Interlude: Digital Subjectivities
}

\section{Claire Larsonneur}

\section{(2) OpenEdition}

\section{Journals}

Electronic version

URL: https://journals.openedition.org/angles/860

DOI: 10.4000/angles.860

ISSN: 2274-2042

\section{Publisher}

Société des Anglicistes de l'Enseignement Supérieur

\section{Electronic reference}

Claire Larsonneur, "Graphic Interlude: Digital Subjectivities", Angles [Online], 7 | 2018, Online since 01 November 2018, connection on 10 June 2022. URL: http://journals.openedition.org/angles/860 ; DOI: https://doi.org/10.4000/angles.860

This text was automatically generated on 10 June 2022.

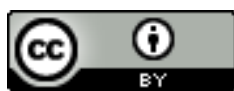

Angles est mise à disposition selon les termes de la Licence Creative Commons Attribution 4.0 International. 


\title{
Graphic Interlude: Digital Subjectivities
}

\author{
Claire Larsonneur
}

\section{EDITOR'S NOTE}

All pictures are by Claire Larsonneur.

\section{Claire Larsonneur, Blue Babies}

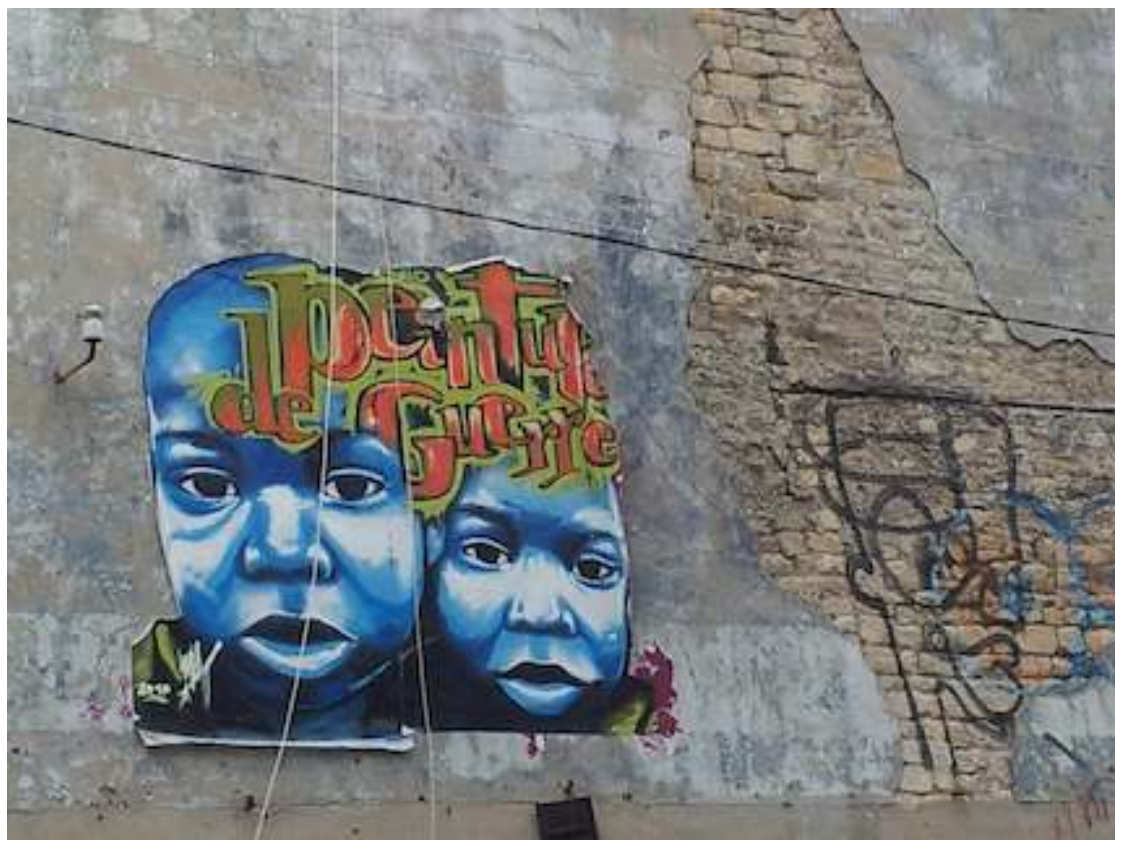

I heard a discordant voice. Its owner addressed us from a ceiling hatch. Whether her webbed lips, crescent eyes and disconnected speech were genomed or mutated I could not be sure. Her gem-warted fingers gripped the hatch-ridge. (David Mitchell, Cloud Atlas, London: Sceptre, 2004: 333) 


\section{Claire Larsonneur, Mechanical Girl}

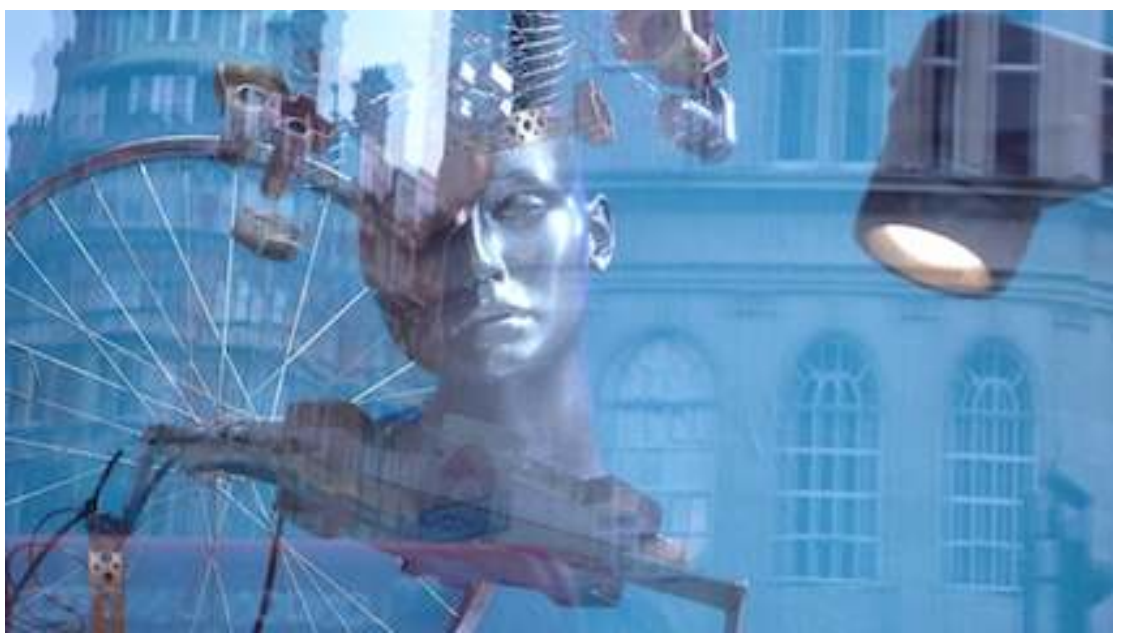

La machine gouverne. La vie humaine est rigoureusement enchaînée par elle, assujettie aux volontés terriblement exactes des mécanismes. Ces créatures des hommes sont exigeantes. Elles réagissent à présent sur leurs créateurs et les façonnent d'après elles. Il leur faut des humains bien dressés ; elles en effacent peu à peu les différences et les rendent propres à leur fonctionnement régulier, à l'uniformité de leurs régimes. Elles se font donc une humanité à leur usage, presqu'à leur image.. (Paul Valéry, Essais quasi politiques, Euvres complètes, Paris: Gallimard, Pléiade, 1957: 357)

Claire Larsonneur, The Warrior in the Clouds

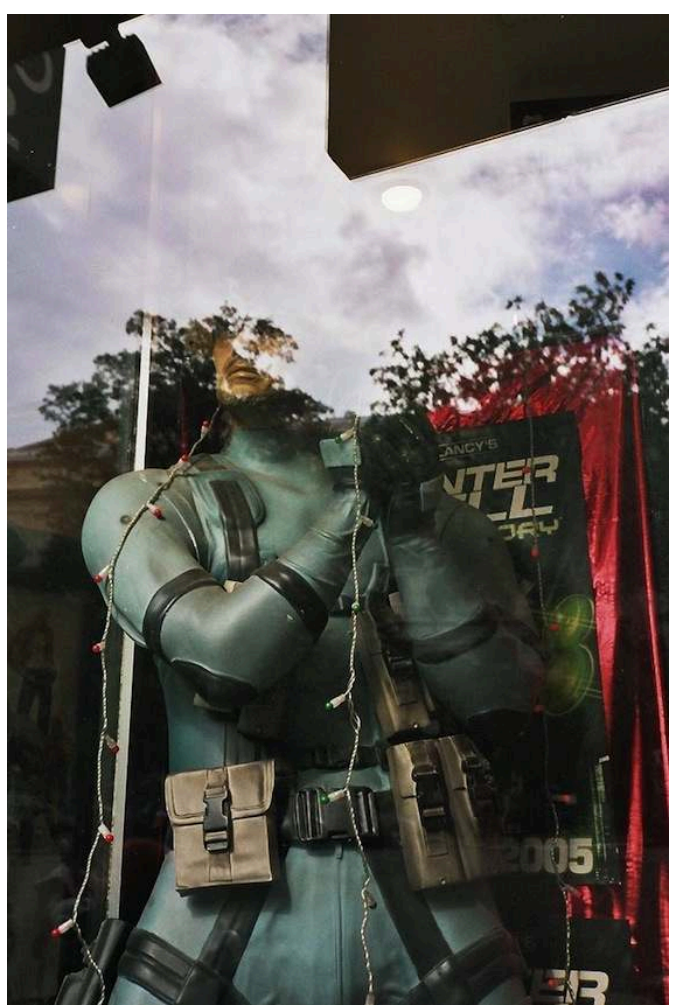

Je sais, siffla-t-il, que vous êtes un cyborg. [...] Je sais qu'on vous a transformé en machine de combat, monsieur Fitzgerald. Qu'on voulait faire de vous le soldat du vingt et unième siècle. Des amplificateurs de force ont été implantés dans vos 
muscles. Des pans entiers de votre squelette - votre bras droit, par exemple - ont été remplacés par des armatures en titane hautement concentré. Des capteurs électroniques vous permettent de percevoir les ultraviolets, les infrarouges, les rayons $\mathrm{X}$ et gamma, les virus, les armes chimiques etc. (A. Eschbach, Le Dernier de son espèce, 2003. Trans. from the German by J.Bernhardt and C. Duval, Nantes: L'Atalante, 2006: 66-7)

Claire Larsonneur, Underwear Robot

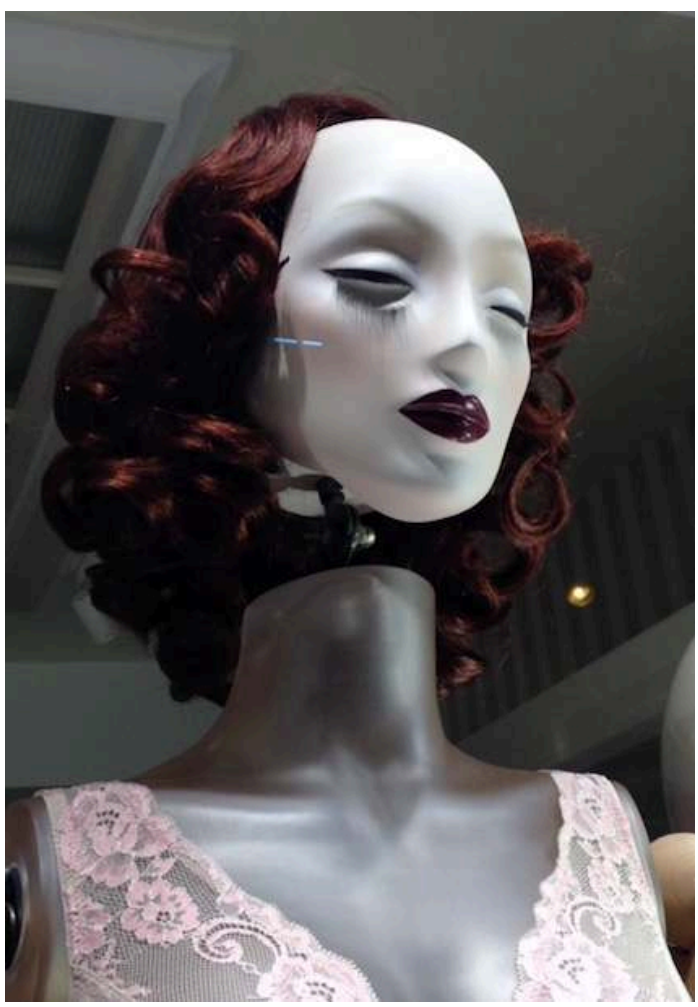

My lover is made of meta-material, a polymer tough as metal, but pliable and flexible and capable of heating and cooling, just like a human skin. She has an articulated titanium skeleton and a fibre-optic neural highway. She has no limbic system because she is not designed to feel emotion.

she has no blood.

She can't give birth.

Her hair and nails don't grow.

She doesn't eat or drink.

She is solar-powered.

She has learned how to cry. (Jeanette Winterson, The Stone Gods, London: Penguin, 2007: 83) 


\section{Claire Larsonneur, Doll}

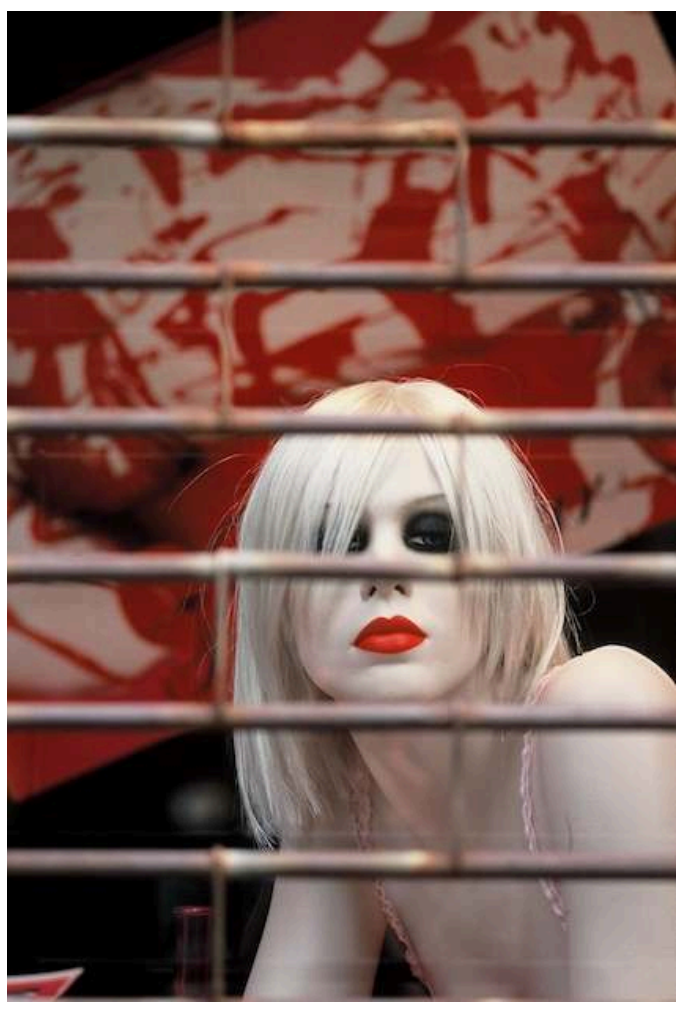

He turned on the computer and made sure all the settings were correct. Then he took off her head, placed everything inside and secured it, and put her carefully back together.

'Now I can really talk to you,' said Yukio as he looked at her face to see if it had changed. 'Your computer will recognize words and phrases I say, or things I send you by email. And it can generate voice so you can even talk back to me! I chose such a beautiful voice for you, Yukiko, and I made up such nice phrases for you to say. Say something!'

'Yukio,' said Yukiko. (Rana Dasgupta, 'The Doll', Tokyo Cancelled, Black Cat, 2005.) 


\section{Claire Larsonneur, Translucent}

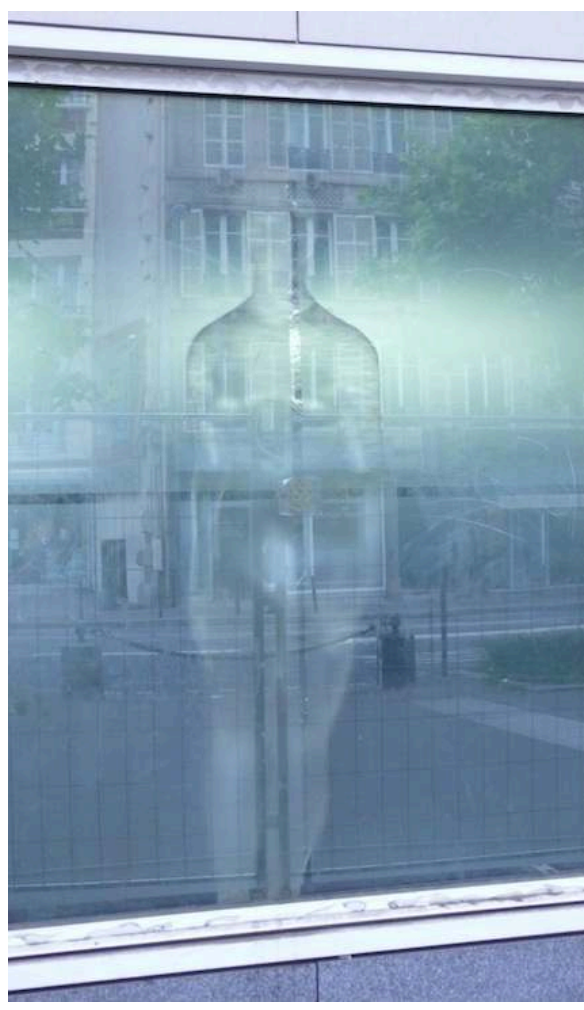

There are a couple of translucents serving behind the bar.

Translucents are see-through people. When you fuck them you can watch yourself doing it. It's pornography for introverts. (Jeanette Winterson, The Stone Gods, London: Penguin, 2007: 22-3)

\section{Claire Larsonneur, Grim Eyes}

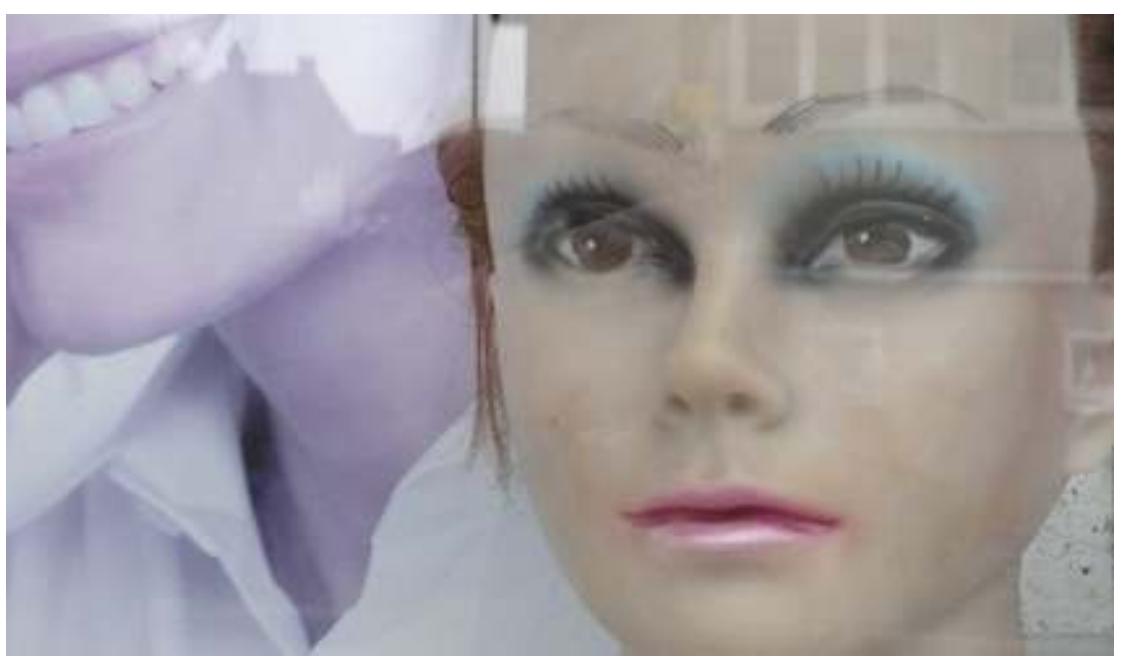

I went downstairs, through the clotted ranks of Security and Support, officially known as Enforcement Services and Enhancement Services, but the SS has a better ring to it than the EE. We work together a lot of the time, soft-cop hard-cop kind of thing. It's my job - that is, our job -in Enhancement to explain to people that they really do want to live their lives in a way that is good for them and good for the Community. Enforcement steps in when it doesn't quite work out. (Jeanette Winterson, The Stone Gods, London: Penguin, 2007: 22-3) 


\section{ABSTRACTS}

This graphic interlude features a selection of pictures from Figures urbaines, a photographic series by Claire Larsonneur, which was displayed at the Usine Utopik and the château of Cerisy la Salle during the Posthuman seminar in June 2016. Each picture echoes an excerpt from sciencefiction. All photographs were taken in public spaces and are unedited: those urban figures were graffiti, shop displays, reflections and may no longer exist.

Cet interlude iconographique comporte une sélection d'images de Figures urbaines, une série photographique de Claire Larsonneur, exposée à l'Usine Utopik et au château de Cerisy la Salle dans le cadre du colloque Posthumains et subjectivités numériques, juin 2016. Chaque image fait écho à un texte de science-fiction. Toutes les photographies ont été prises dans l'espace public, sans retouches: ces figures urbaines furent des graffiti, des installations en vitrine, des reflets et n'existent sans doute déjà plus.

\section{INDEX}

Mots-clés: vidéo, art, sujet digital, Intelligence Artificielle (IA), technologie, robotique, littérature, propriété intellectuelle

Keywords: video, digital subjectivity, Artificial Intelligence (AI), technology, robotics, literature, art, copyright

\section{AUTHOR}

\section{CLAIRE LARSONNEUR}

Senior Lecturer, currently working at the EA 1569 TransCrit, Université de Vincennes - Paris 8. Claire Larsonneur does research in Translation studies, English Literature and Digital Humanities. She is currently working on a project on Digital authorship. Contact: claire.larsonneur [at] univ-paris8.fr. 